\title{
Ocular injuries and eye care seeking patterns following injuries among cocoa farmers in Ghana.
}

\author{
Boadi-Kusi Samuel Bert ${ }^{1,2}$, Hansraj Rekha ${ }^{1}$, Mashige Khathutshelo Percy ${ }^{1}$
}

\begin{abstract}
1. Discipline of Optometry, School of Health Sciences, University of KwaZulu-Natal, Durban 4000, South Africa. Private Bag X54001.

2. Department of Optometry, School of Allied Health Sciences, University of Cape Coast, Cape Coast, Ghana. PMB.
\end{abstract}

\begin{abstract}
Background: The work environment of cocoa farmers exposes them to several ocular hazards that predispose them to eye diseases and injuries. However, the extent of ocular injuries and health seeking patterns following these injuries are unknown among cocoa farmers in Ghana.

Objectives: To determine the prevalence of ocular injuries and health seeking behaviour following injury among cocoa farmers in Ghana.

Methods: Five hundred and fifty six participants were recruited through simple random sampling using a multistage approach from four cocoa growing districts in Ghana. A structured questionnaire was used to collect relevant information such as demography, ocular hazards and injuries experienced. An ocular examination was also conducted to assess the eye health of the participants. Descriptive and regression statistics were used to analyze the data. The rate of ocular injuries was calculated by using the number of injuries reported that resulted in lost work time/days divided by the number of worker years at risk of injury (sum of years worked in cocoa farms for all the participants).

Results: The rate of ocular injuries was 11.3/1000 worker years (95\% CI: 9.4 - 31) which led to lost work time of 37.3/1000 worker years (95\% CI: 34.1 - 40.8). The major causes of ocular injury were plants/branches $(\mathrm{n}=73,51.1 \%)$, chemicals $(\mathrm{n}=27$, $18.9 \%)$, cocoa pod/husk $(\mathrm{n}=14,9.8 \%)$ and occurred mostly during weeding, harvesting and chemical spraying. Few ( $\mathrm{n}=34$, $6.1 \%)$ participants reported the use of ocular protection. Fifty-five (38.5\%) participants visited the local chemical shops, while $37(25.9 \%)$ visited hospitals/clinics for ocular treatment of their injuries.

Conclusion: There is a high rate of ocular injuries among cocoa farmers who make insufficient use of appropriate eye care services. There is the need for eye health education among cocoa farmers in Ghana.

Keywords: Ocular injuries, cocoa farmers, ocular protective device, eye care services

DOI: http://dx.doi.org/10.4314/ahs.v16i1.34

Cite as: Bert B-KS, Rekha H, Percy MK. Ocular injuries and eye care seeking patterns following injuries among cocoa farmers in Ghana. Afri Health Sci. 2016;16(1): 255- 265. http:/ / dx.doi.org/10.4314/abs.v16i1.34
\end{abstract}

\section{Introduction}

Cocoa farming is predominant in the agricultural sector of Ghana, employing more than 800000 small holder farm households and providing employment opportunities for others engaged in related activities such as purchases, transportation and processing ${ }^{1,2}$. It plays a vital role in the Ghanaian economy, providing employment to approximately 50 percent of the agricultural workforce $e^{3,4}$. Therefore, factors that negatively impact on the general and ocular health of this workforce will adversely affect

\section{Corresponding author: \\ Boadi-Kusi Samuel Bert, \\ Tel: +233-20-8752876 \\ Email: sboadi-kusi@ucc.edu.gh}

the production of cocoa in Ghana. The process of cocoa farming in Ghana involves land preparation which starts with clearing of weeds, cutting down trees, drying and burning of the bushes, as well as, removal of remains of trees after burning and planting among others. Farmers normally use hand held equipment such as machetes, harvesting hooks, pick axes, hoes, spraying machines, etc in their activities. Application of chemicals such as weedicides, fungicides, pesticides and fertilizers is a common practice among these farmers. These activities have the potential to cause ocular injuries among the farmers. In spite of these inherent dangers from cocoa farming, no policy exists in Ghana for the occupational health and safety of agricultural workers ${ }^{5,6}$, although Ghana ratified the ILO Convention 184 on Occupational Health and Safety for agricultural workers in $2011^{7,8}$. 
Although the economy of Ghana is largely dependent on cocoa farming, there is a paucity of information on the ocular health of these workers in Ghana ${ }^{3}$. While data on ocular injuries in other industries in Africa exists, information on ocular injuries in agriculture is limited. A few studies have highlighted ocular injuries and irritation among farmers in developing African countries such as Ghana $^{9,10}$, Ethiopia ${ }^{11}$, Tanzania ${ }^{12}$ and Malawi ${ }^{13}$. In some instances, these reports lack a clear definition of what constitutes ocular injury. Similarly, information on the use of ocular protective equipment and health seeking behaviour following injury is limited in the literature on African farmers. The lack of such information makes it difficult to develop training interventions to address farmers' specific needs, and to improve their knowledge about eye health and safety. The current study therefore, sought to investigate the occurrence of ocular injuries, use of ocular protective devices and utilization of eye care services following such injuries among cocoa farmers in Ghana.

\section{Methods}

A cross-sectional survey was conducted among farmers selected from four cocoa growing districts in Ghana; Juaboso (Western), Kwahu West (Eastern), Atwima Mponua (Ashanti) and Assin North (Central). While many of the farms are small, the areas in which they are located tend to be rural in nature, with people living in villages that are connected by poorly serviced road infrastructure and inadequate health services. Farm workers constitute a 'hard-to-reach' population ${ }^{14,15}$ therefore, a simple random sampling procedure through a multistage approach was employed, to reduce the likelihood of selection bias. This was consistent with other studies conducted among the study population ${ }^{16,17}$. The cross-sectional study involved the administration of a structured questionnaire and an ocular health assessment to confirm eye conditions (i.e. corneal opacities/scars, etc.) that occurred due to ocular injuries. However, the absence of any such conditions did not nullify a history of ocular injury. The questionnaire included questions designed to assess the participants' demographic details, ocular complaints, ocular hazards and injuries experienced in the farms, utilization of ocular protection and specific health/eye care seeking patterns following injuries. Most of the questions were formulated following a thorough review of existing literature on the subject. ${ }^{18,19,20,21}$ The questionnaire also included questions/statements on several aspects of ocular injuries such as the number of workdays lost due to eye injuries, as well as, causes and severity of injuries.

\section{Sampling procedure and sample size}

Following the selection of twenty villages from the four districts through random sampling using the multistage approach, societal heads and chief cocoa farmers in the selected villages assisted with the compilation of a list of all cocoa farmers in the villages to constitute a sampling frame out of which participants of the study were randomly selected. A proportion of the sample size was assigned to each village based on the population size of the settlement to give equal weighting ${ }^{16,17}$. As a result, an average of 25 participants was selected from each of the five villages in each district to constitute the study sample. Where a selected farmer declined to participate or was unavailable, they were replaced through the same process of selection.

The sample size for the study was determined by using the formula, $\mathrm{n}=\mathrm{Z}^{2}(1-\alpha / 2) \mathrm{pq} / \mathrm{d}^{2}$ where, $\mathrm{Z}=1.96$ at 95\% confidence, $\alpha=0.05, \mathrm{p}=$ prevalence of ocular injury, $\mathrm{q}=1-\mathrm{p}, \mathrm{d}=$ absolute allowable error, assumed to be $10 \%$ (i.e. $p=0.1$ and $q=0.9$ ), a precision (d) of $\pm 3 \%$ and design effect of 1.5 , and a sample size of 576 cocoa farmers were required ${ }^{22}$. Farmers 18 years and older, engaged in production activities on the farm for a minimum period of 3 years (average gestation period for a cocoa tree) and who worked only on a cocoa farm were included in the study.

\section{Data collection}

Face to face interviews were conducted with participants using a structured questionnaire. Three interviewers who were university graduates with relevant experiences in data collection and who underwent a training session for 2 days were involved in the data collection while certified optometrists conducted the ocular examinations.

Participants reported eye injuries sustained within the last one year preceding the study, activity on the farm during which the injury occurred, cause of the injury, as well as, health intervention sought if any. Ocular injury in this study was defined as any injury occurring to the eye and/ or adnexa that occur in the workplace and required medical attention (orthodox or traditional) or results in at least one or more days of restricted activities ${ }^{18,23,24,25}$. Participants also reported the use of ocular protection, if any, and on the day injury occurred.

African Health Sciences Vol 16 Issue 1, March 2016 


\section{Analysis}

Descriptive statistics were computed for sample demographics and farm characteristics. Pearson's chi square or Fisher's exact test (where indicated) were used to test associations between variables measured. Differences in test were considered significant if $p<0.05$. Where variables under investigation were unevenly distributed, the Wilcoxon rank sum test was used and the median and inter-quartile range (IQR) reported accordingly. Bivariate logistic regression was also used to predict the odds of sustaining an eye injury based on some defined exposure, demographics, as well as, farm characteristics supported by the literature ${ }^{18,21,26}$. The odds ratio, at a $95 \%$ confidence interval, for the results was also presented.

To calculate the rate of ocular injuries for the sample, the number of injuries reported that resulted in one or more days of lost work time was divided by the number of worker years at risk of injury. The variable worker years at risk was calculated by summing the self-reported years of working in cocoa farms for all 556 farmers. Confidence interval for the rate was calculated assuming a simple random sample $e^{20,27}$.

\section{Ethical approval}

Ethical approval for this study was obtained from the Ghana Health Service Ethics Committee on Research involving Human Subjects (GHS- ECRHS). Participants signed or thumb printed informed consent prior to data collection, and the principles of privacy and confidentiality were adhered to in this study.

\section{Results}

Five hundred and fifty-six out of the 576 participants who were recruited completed the study $(\mathrm{N}=556)$, and included 359 (64.6\%) males and 197 (35.4\%) females with a mean age of 54.9 years $( \pm 11.2)$. Other demographic characteristics of cocoa farmers are illustrated in Table 1.

Table 1: Demographic characteristics of cocoa farmers

\begin{tabular}{|c|c|c|c|c|}
\hline \multirow{2}{*}{$\begin{array}{l}\text { Demographic } \\
\text { characteristics }\end{array}$} & \multicolumn{2}{|l|}{ Sex } & \multirow[b]{2}{*}{ Total } & \multirow[b]{2}{*}{$p$-value } \\
\hline & $\begin{array}{l}\text { Male } \\
\mathrm{n}=359\end{array}$ & $\begin{array}{l}\text { Female } \\
\mathbf{n}=197\end{array}$ & & \\
\hline \multicolumn{5}{|l|}{ Age n (\%) } \\
\hline$<40$ & $29(8.1)$ & $157.6)$ & $44(7.9)$ & 0.970 \\
\hline $40-49$ & $85(23.7)$ & $48(24.4)$ & $133(23.9)$ & \\
\hline $50-59$ & $115(32.0)$ & $66(33.5)$ & $181(32.6)$ & \\
\hline$\geq 60$ & $130(36.2)$ & $68(34.5)$ & $198(35.6)$ & \\
\hline Age/yrs (Mean SD) & $55.2(11.2)$ & $54.6(11.0)$ & $54.9(11.2)$ & 0.548 \\
\hline \multicolumn{5}{|l|}{ Education n (\%) } \\
\hline No Education & $69(19.2)$ & $73(37.1)$ & $142(25.5)$ & $<0.001$ \\
\hline Primary & $51(14.2)$ & $25 \quad(12.7)$ & $76(13.7)$ & \\
\hline Middle/JHS & $210(58.5)$ & 91 (46.2) & $301(54.1)$ & \\
\hline Sec/Post Sec & $29(8.1)$ & $8 \quad(4.1)$ & $37(6.7)$ & \\
\hline \multicolumn{5}{|l|}{ Income n $(\%)$} \\
\hline$<5000$ & $233(62.1)$ & $164(83.3)$ & $387(69.6)$ & $<0.001^{\mathrm{a}}$ \\
\hline 5000-9999 & $89(24.8)$ & $30(15.2)$ & $119(21.4)$ & \\
\hline $10000-14999$ & $28(7.8)$ & $2(1.0)$ & $30(5.4)$ & \\
\hline$\geq 15000$ & $19(5.29)$ & $1(0.5)$ & $20(3.6)$ & \\
\hline \multicolumn{5}{|l|}{ Marital status n (\%) } \\
\hline Never married & $2(0.6)$ & $3(1.5)$ & $5(0.9)$ & $<0.001^{a}$ \\
\hline Married & $265(73.8)$ & $93(47.2)$ & $358(64.4)$ & \\
\hline Living together & $65(18.1)$ & $20(10.2)$ & $85(15.3)$ & \\
\hline Divorced & $13(3.6)$ & $41(20.8)$ & $54(9.7)$ & \\
\hline Widowed & $14(3.9)$ & $40(20.3)$ & $54(9.7)$ & \\
\hline \multicolumn{5}{|l|}{ Family size n $(\%)$} \\
\hline$>4$ & $7(1.95)$ & $11(5.6)$ & $18(3.2)$ & $<0.001$ \\
\hline $4-6$ & $113(31.5)$ & $79(40.0)$ & $192(34.5)$ & \\
\hline $7-9$ & $131(36.5)$ & $84(42.6)$ & $215(38.7)$ & \\
\hline$\geq 10$ & $108(30.1)$ & $23(11.7)$ & 131 (23.6) & \\
\hline Family size (Mean, SD) & $8.3(3.4)$ & $6.9(2.2)$ & $7.8(3.1)$ & $<0.001$ \\
\hline
\end{tabular}


Most of the participants had spent a greater part of their active years in cocoa farming (23.1 SD \pm 12.5$)$ and gener- ally worked on smaller farm sizes, 8 (IQR:5-14) for males and 5 (IQR:3-9) for females, $(\mathrm{p}<0.001)$ (Table 2).

Table 2: Farm characteristics of cocoa farmers

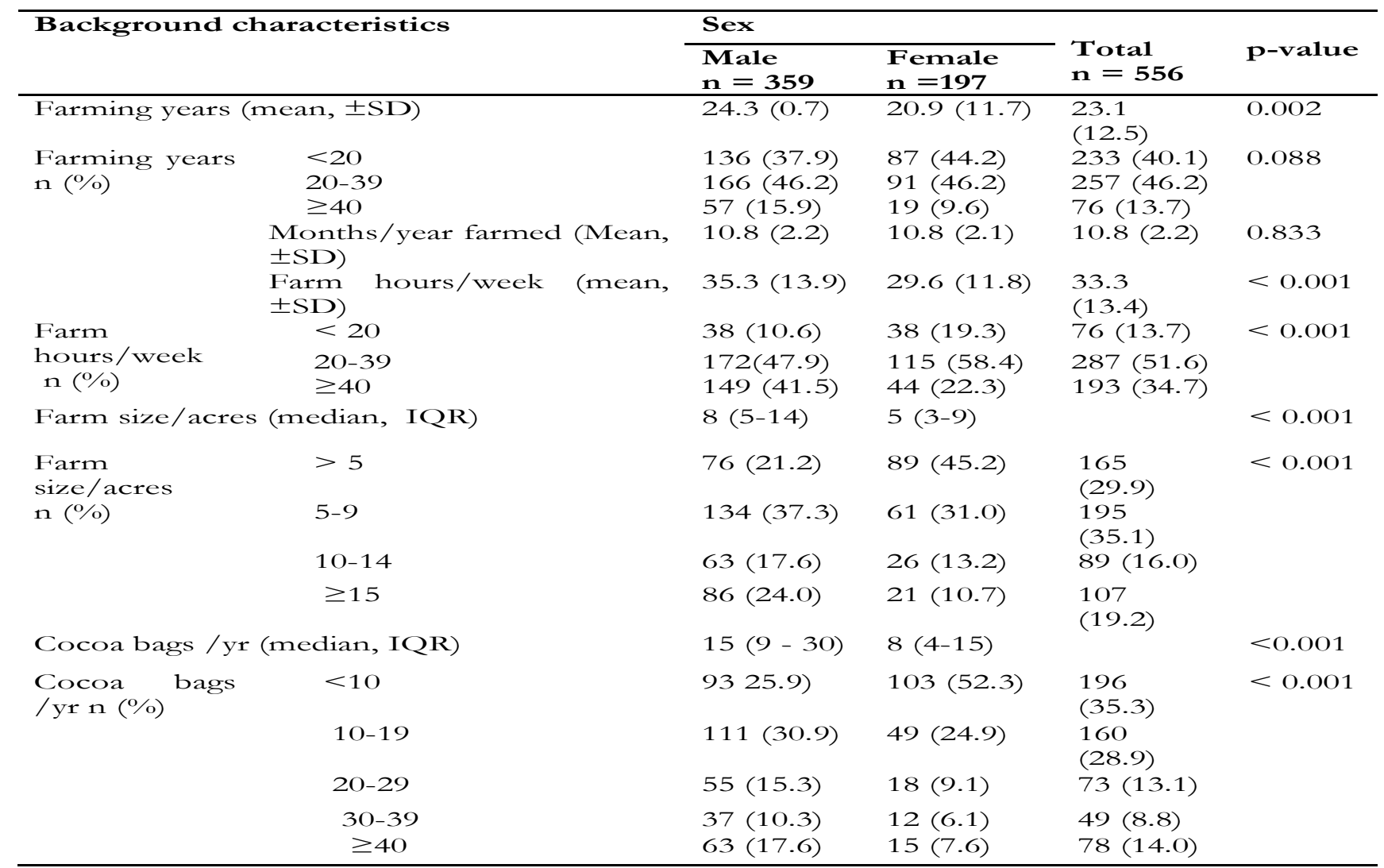

$\mathrm{a}=$ Fisher's exact test

Several ocular complaints were reported by the par- $(33.3 \%)$. Others are shown in Figure 1. ticipants, the most common being poor distance vision

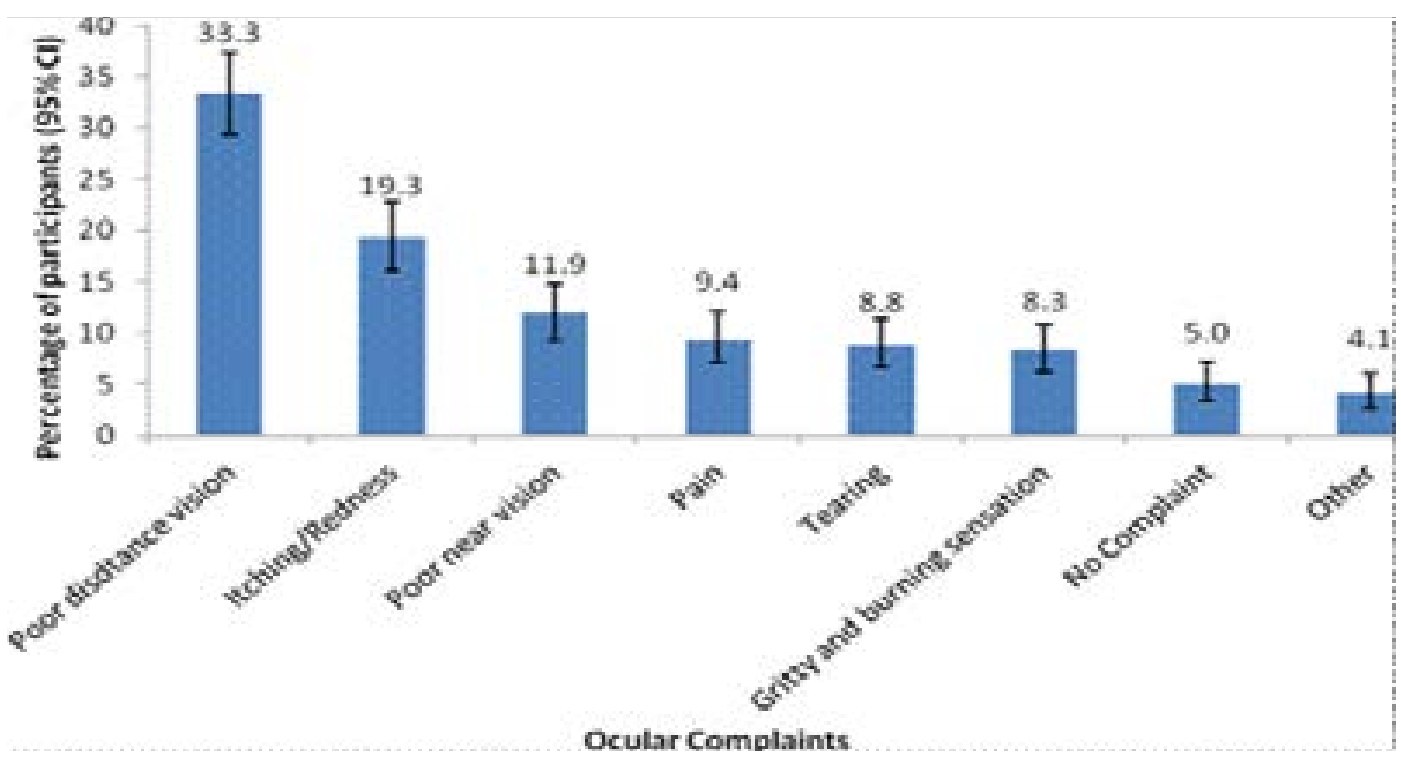

Figure 1: Ocular complaints among participants 
Among those with ocular complaints, 353 (66.9\%) participants attributed their eye symptoms to the activities they are engaged in on the farm. The most common ocu- lar hazards reported by participants included ultraviolet radiation from the sun (94.1\%), chemicals (64\%), dust/ sand and stones (47.1\%) as indicated in Figure 2.

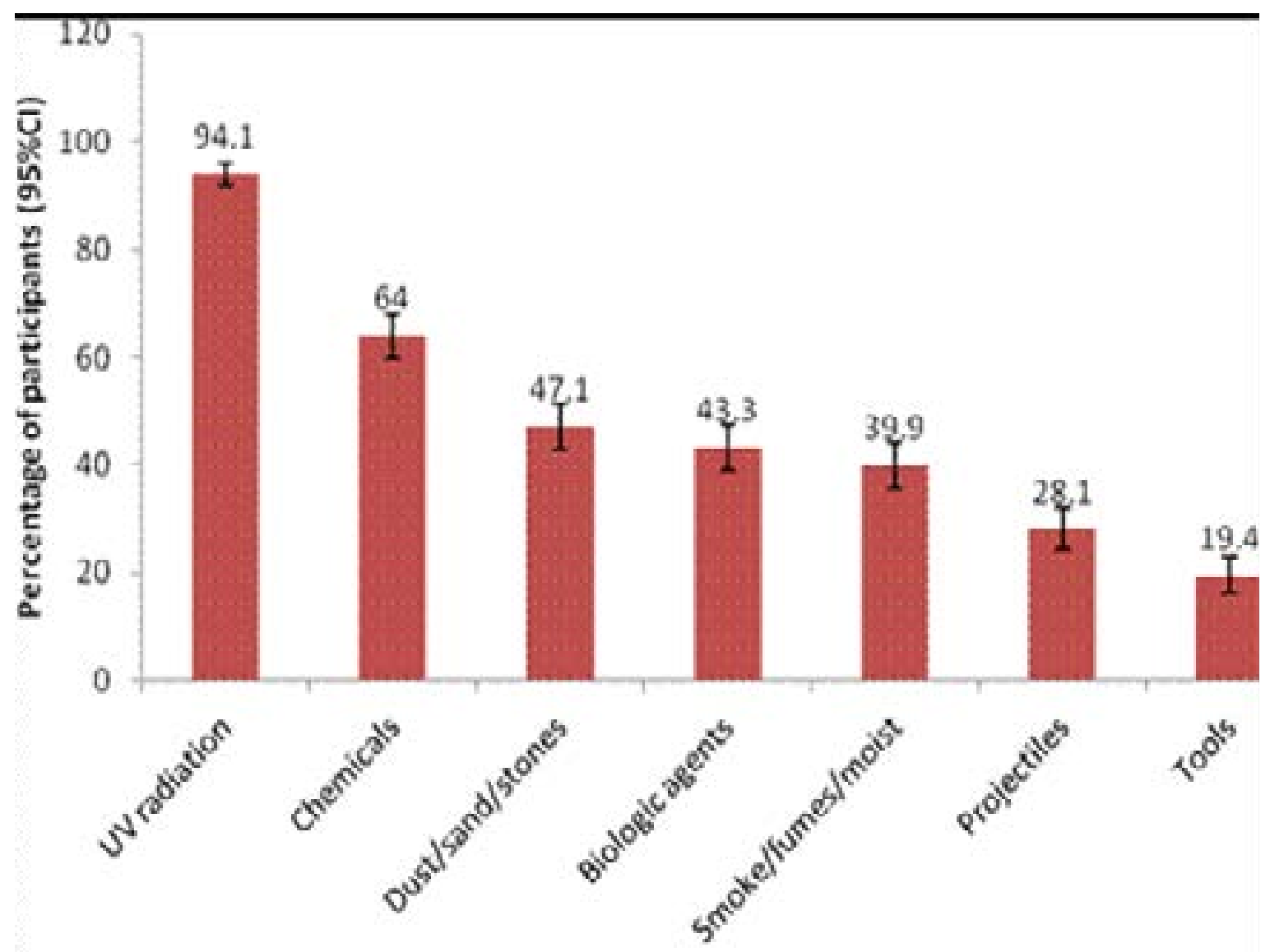

Reported ocular hazards on cocoa farms

Figure 2: Reported ocular hazards on farms

Based on reported years worked in agriculture for all 556 workers, the sample had a total of 12854.5 years worked on cocoa farms. The rate of eye injuries was 143/12 854.5 worker years or $11.3 / 1000$ worker years (95\% CI 9.4, 31.0). Similarly, the rate of lost work time injuries was 137 injuries/12 854.5 worker years or 37.3/1000 worker years (95\% CI: 34.1, 40.8), with three injuries resulting in permanent blindness in the affected eye that led to more than 14 days of lost work time. The crude prevalence of reported ocular injuries within the one year preceding this study was 143 (25.7\%) among the study participants, with a mean loss of workdays due to eye injury of $3.4(95 \%$ CI: 3.1-3.6) (Table 3).
Most of the injuries occurred while participants were weeding ( $\mathrm{n}=65,45.6 \%$ ). The major causes of ocular injury among the participants were plants/branches ( $\mathrm{n}=$ $73,51.1 \%)$ and chemicals ( $n=27,18.9 \%)$. Using a pain scale of 1-10, participants indicated that their eye injuries were very severe $(\mathrm{n}=72,50.4 \%)$. The use of ocular protection was reported by $34(6.1 \%)$ participants, with the main types being goggles $(n=24,70.6 \%)$. Ocular protection was mainly used during chemical application (spraying) ( $\mathrm{n}=31,91.2 \%)$. However, only one $(0.7 \%)$ participant reported using ocular protection at the time of injury (Table 3). 
Table 3: Ocular injury and utilization of health services

\begin{tabular}{|c|c|c|}
\hline Factor & Response & Frequency n (\%) \\
\hline Injury (one year) & Yes & $143(25.7)$ \\
\hline \multirow{6}{*}{$\begin{array}{l}\text { Loss work days (mean, 95\% } \\
\text { Activity during which } \\
\text { injury occurred }\end{array}$} & CI) & $3.4(3.1-3.6)$ \\
\hline & Weeding & $65(45.6)$ \\
\hline & Harvesting of cocoa pods & $39(27.3)$ \\
\hline & Spraying & $27(18.9)$ \\
\hline & Pruning & $11(7.7)$ \\
\hline & Bush burning & $1(0.7)$ \\
\hline \multirow[t]{7}{*}{ Cause of injury } & Plant/branches & $73(51.1)$ \\
\hline & Chemical & $27(18.9)$ \\
\hline & Cocoa pod/husk & $14(9.8)$ \\
\hline & Flying objects & $13(9.1)$ \\
\hline & Sand/stone & $11(7.7)$ \\
\hline & Hand tool & $4(2.8)$ \\
\hline & Insect & $1(0.7)$ \\
\hline \multirow[t]{3}{*}{ Severity of injury } & Very severe & $72(50.4)$ \\
\hline & Severe & $65(45.5)$ \\
\hline & Not severe & $6(4.2)$ \\
\hline Use of ocular protection & Yes & $34(6.1)$ \\
\hline \multirow[t]{3}{*}{ Type of ocular protection } & Goggles & $24(70.6)$ \\
\hline & Protective glasses & $4(11.8)$ \\
\hline & Other & $6(17.7)$ \\
\hline $\begin{array}{l}\text { Was using ocular } \\
\text { protection at the time of } \\
\text { injury }\end{array}$ & & $1(0.7)$ \\
\hline \multirow{4}{*}{$\begin{array}{l}\text { Place of intervention } \\
\text { sought after injury }\end{array}$} & Chemical shop & $55(38.5)$ \\
\hline & Hospital/clinic & $37(25.9)$ \\
\hline & Herbal doctor & $27(18.9)$ \\
\hline & $\begin{array}{l}\text { Self medication } \\
\text { (traditional) }\end{array}$ & $24(16.8)$ \\
\hline Registered with the & Yes & $460(82.7)$ \\
\hline $\begin{array}{l}\text { National Health } \\
\text { Insurance Scheme }\end{array}$ & No & $96(17.3)$ \\
\hline
\end{tabular}

Thirty-nine percent of the participants who reported having sustained ocular injuries sought medical intervention from chemical shops. Other health seeking patterns following ocular injuries are illustrated in Table 3. Most participants $(82.7 \%)$ were registered with the National Health Insurance Health Scheme (NHIS). An ocular assessment showed that eye injuries caused corneal scars and opacities among $34(6.1 \%)$ participants and led to permanent blindness in one eye of three participants.
Males were more likely to experience corneal opacities/ scars than females $(p=0.025)$.

A bivariate analysis of factors that may have influenced the occurrence of ocular injuries indicated that working more than 40 hours per week, (OR 2.09, $1.08-4.03, \mathrm{p}=$ 0.027 ), perception of poor near vision (OR 1.26, 1.05 $1.52, \mathrm{p}=0.015)$, spraying chemicals (OR 2.58, $1.74-3.82$, $\mathrm{p}<0.001)$ and harvesting of cocoa pods (OR 2.63, 1.27 $-5.44, \mathrm{p}=0.009$ ) were associated with eye injuries (Table 4). 
Table 4: Factors influencing the occurrence of eye injury

\begin{tabular}{|c|c|c|}
\hline Factor & $\begin{array}{l}\text { Bivariate regression (unadjusted). Odds } \\
\text { ratio }(95 \% \mathrm{CI})\end{array}$ & $\mathrm{p}$-value \\
\hline $\begin{array}{l}\text { Sex } \\
\text { Male R } \\
\text { Female }\end{array}$ & $\begin{array}{l}1.00[1.00-1.00] \\
0.72[0.48-1.09]\end{array}$ & $\begin{array}{l}1.000 \\
0.121\end{array}$ \\
\hline $\begin{array}{l}\text { Age } \\
<40 \mathrm{R} \\
40-49 \\
50-59 \\
\geq 60 \\
\end{array}$ & $\begin{array}{l}1.00[1.00-1.00] \\
0.72[0.34-1.55] \\
1.12[0.55-2.30] \\
0.62[0.29-1.29]\end{array}$ & $\begin{array}{l}1.00 \\
0.408 \\
0.749 \\
0.205 \\
\end{array}$ \\
\hline $\begin{array}{l}\text { Education } \\
\text { No education R } \\
\text { Primary } \\
\text { Middle/JSS } \\
\text { Sec/Post Sec }\end{array}$ & $\begin{array}{l}1.00[1.00-1.00] \\
1.26[0.68-2.32] \\
0.74[0.46-1.17] \\
2.32[1.10-4.90]\end{array}$ & $\begin{array}{l}1.00 \\
0.453 \\
0.200 \\
0.026^{*}\end{array}$ \\
\hline $\begin{array}{l}\text { Years of farming } \\
<20 \mathrm{R} \\
20-39 \\
\geq 40\end{array}$ & $\begin{array}{l}1.00[1.00-1.00] \\
1.14[0.76-1.73] \\
1.12[0.62-2.03]\end{array}$ & $\begin{array}{l}1.00 \\
0.510 \\
0.714\end{array}$ \\
\hline $\begin{array}{l}\text { Farm size } \\
<5 \mathrm{R} \\
5-9 \\
10-14 \\
\geq 40\end{array}$ & $\begin{array}{l}1.00[1.00-1.00] \\
1.59[0.98-2.59] \\
0.97[0.51-1.85] \\
1.79[1.03-3.12]\end{array}$ & $\begin{array}{l}1.00 \\
0.062 \\
0.943 \\
0.039 *\end{array}$ \\
\hline $\begin{array}{l}\text { Work hours/week } \\
\quad<20 \mathrm{R} \\
20-39 \\
\geq 40\end{array}$ & $\begin{array}{l}1.00[1.00-1.00] \\
1.35[0.71-2.56] \\
2.09[1.08-4.03]\end{array}$ & $\begin{array}{l}1.00 \\
0.361 \\
0.027 *\end{array}$ \\
\hline $\begin{array}{l}\text { Perception of DVA } \\
\text { Good R } \\
\text { Poor }\end{array}$ & $\begin{array}{l}1.00[1.00-1.00] \\
0.69[0.51-0.94]\end{array}$ & $\begin{array}{l}1.00 \\
0.017^{*}\end{array}$ \\
\hline $\begin{array}{l}\text { Perception of NVA } \\
\text { Good R } \\
\text { Poor }\end{array}$ & $\begin{array}{l}1.00[1.00-1.00] \\
1.26[1.05-1.52]\end{array}$ & $\begin{array}{l}1.00 \\
0.015^{*}\end{array}$ \\
\hline $\begin{array}{l}\text { Weeding } \\
\text { Yes } \\
\text { No R } \\
\end{array}$ & $\begin{array}{l}2.11[0.45-9.54] \\
1.00\end{array}$ & $\begin{array}{l}0.332 \\
1.00\end{array}$ \\
\hline $\begin{array}{l}\text { Bush burning } \\
\text { Yes } \\
\text { No R }\end{array}$ & $\begin{array}{l}1.58[0.80-1.20] \\
1.00\end{array}$ & $\begin{array}{l}0.192 \\
1.00\end{array}$ \\
\hline $\begin{array}{l}\text { Fertilizing } \\
\text { Yes } \\
\text { No R } \\
\end{array}$ & $\begin{array}{l}1.51[0.9-2.33] \\
1.00\end{array}$ & $\begin{array}{l}0.066 \\
1.00\end{array}$ \\
\hline $\begin{array}{l}\text { Spraying } \\
\text { Yes } \\
\text { No R } \\
\end{array}$ & $\begin{array}{l}2.58[1.74-3.82] \\
1.00\end{array}$ & $\begin{array}{l}<0.001 * \\
1.00\end{array}$ \\
\hline $\begin{array}{l}\text { Pruning } \\
\text { Yes } \\
\text { No R } \\
\end{array}$ & $\begin{array}{l}1.82[0.87-3.83] \\
1.00\end{array}$ & $\begin{array}{l}0.114 \\
1.00 \\
\end{array}$ \\
\hline $\begin{array}{l}\text { Harvesting } \\
\text { Yes } \\
\text { No R }\end{array}$ & $\begin{array}{l}2.63[1.27-5.44] \\
1.00\end{array}$ & $\begin{array}{l}0.009 * \\
1.00\end{array}$ \\
\hline
\end{tabular}

$*$ = significant $\mathrm{p}$ - value, $\mathrm{D}=$ Distance, $\mathrm{N}=\mathrm{Near}, \mathrm{VA}=$ Visual Acuity

\section{Discussion}

The predominance of male cocoa farmers in this study is consistent with reports in the literature ${ }^{2,16}$. This may be due to the fact that men are given preference in acquiring land for cash crop farming, and that land is inherited through the male descendents ${ }^{28}$. The predominance of males could also be due to the manual nature of farming. Since males are often the bread winners of families, any ocular incapacitation arising out work on the farm may have dire social consequences. The cocoa farmers were relatively older, which is consistent with reports from other studies ${ }^{2,16,29,30}$. Educational attainment among the sample population was low, as one out of every four participants had no formal education. This is consistent with reports that cocoa farmers are mostly illiterates, with many being unable to read or write ${ }^{16,29}$. 
Participants in the current study reported that they are exposed to radiations from the sun, chemicals, dust, sand and stones and farm tools, as reported in other studies $^{18,19,20,31}$. This may in the long-term increase their risk to ocular diseases and injuries particularly if they do not use ocular protective eye wear.

Ocular symptoms reported by participants in this study are similar to those reported among other farmers ${ }^{18,19}$. The crude prevalence of eye injuries among participants in the current study ( $\mathrm{n}=143,25.7 \%)$ was higher than the $19.6 \%$ reported in farmers in a hospital based study in Ghana ${ }^{11}$. However, it was lower than another hospital based study in another African country (Ethiopia), which reported a prevalence of $65 \%$ eye injuries among farm$\mathrm{ers}^{10}$, and the $82.0 \%$ eye injuries and irritations reported among cocoa farmers in a recent baseline report in Ghana. ${ }^{9}$. However, the variability in the exposure of farmers to different conditions and hazards in Ghana and Ethiopia limits direct comparisons. Also, the baseline report by Muillerman ${ }^{9}$ combined both eye injuries and irritations, further preventing direct comparisons between these studies.

Similarly, the rate of eye injuries in this study with respect to worker years and lost work time was higher than the 23.8/10,000 worker years (95\% CI: 17.5-55.9) loss worktime injury reported by Quandt et $\mathrm{al}^{20}$. The rates of injury in this study is also higher than the annual estimated incidence rate (3.46 per 10000 people) of eye injuries among agricultural workers in Nepal ${ }^{32}$. The lost work time due to ocular injury from agricultural activities, with its attended fewer lost workdays of restricted activities (3 days), is similar to the finding of studies reported in the literature ${ }^{33}$. The high prevalence of ocular injuries among cocoa farmers in this study may be due to the wide variety of ocular hazards they face in their daily activities on the farm, as well as, the high level of manual labour involved in cocoa farming ${ }^{18,34,35}$.

Ocular injuries were a major cause of corneal/ opacity or scars in this study and led to three people experiencing permanent blindness in one eye each. Attempts to address the high prevalence of ocular injuries among cocoa farmers should take into consideration the main causes and activities during which eye injuries occurred, such as weeding, harvesting and chemical (pesticides) application.
Ocular health education should therefore, encourage farmers to use ocular protection which recorded a low use in this study, in all activities that have the potential to cause ocular injury, ${ }^{18,20}$ other than only promoting the use of ocular protection during chemical or pesticides application among cocoa farmers ${ }^{36}$. The major causes of ocular injuries in this study highlight the need to enforce the use of ocular protection such as goggles through policy initiatives.

The results of this study suggest that chemical shops provide an important resource for participants in managing the ocular injuries sustained on the farm in rural communities although they are registered with the NHIS and could have sought care from the hospital or clinic. This could be due to the chemical shops being situated within the communities in which farmers live and work, compared to hospitals or clinics that are usually situated several kilometres away. These shops could serve as a conduit for the provision of ocular first aid and subsequent referrals to the hospital/clinics for appropriate remedies if appropriate training and education is given to attendants. The farmers also reported the use of herbal medicine upon sustaining ocular injuries, this having been reported to be widespread in rural communities in Ghana. ${ }^{37}$

The prevalence of use of herbal medicine after an ocular injury was higher than that reported among the general population in the Central Region of Ghana. ${ }^{38}$ In the absence of readily available clinics, the culture of using herbal medicine for a variety of problems is evident in many African countries. ${ }^{39}$ It is important to note that, reporting to these alternate eye care facilities delay seeking appropriate eye care which increases the risk of visual impairment and blindness. There is therefore, the need to educate farmers on the need for seeking prompt and appropriate eye care following ocular injuries.

Furthermore, the possibility of an ocular injury occurring was greater for individuals working more hours (OR 2.09, 95\% CI: 1.08-4.03) on cocoa farms, similar to that reported by other authors in agricultural health studies $^{26,40,41,42}$. An interesting finding in this study is the fact that participants who had poor perception of near vision had a higher probability (OR 1.26, 95\% CI: 1.05 - 1.52) of sustaining ocular injuries. This could be an indication that negative perception could adversely influence hand eye 
coordination, among others consequences, which may lead to ocular injury.

Farmers who were directly involved in the application (spraying) of chemicals had a higher probability of sustaining eye injuries (OR 2.58, 95\% CI: 1.74 - 3.82), as well as, those who were engaged in harvesting of the cocoa pod had a likelihood of 2.63 folds of sustaining ocular injuries than those who were not engaged in these activities, these being reported by other authors ${ }^{9,20,21}$. There is therefore the need to highlight the influence of these farm activities in ocular health education among cocoa farmers in Ghana.

\section{Conclusion and recommendation}

The results of this study show that Ghanaian cocoa farmers could benefit from ocular health education or measures aimed at reducing ocular injury in their workplace. Also, prompt and appropriate eye care should be sought following an injury in order to prevent vision loss. Other preventive measures such as adequate and compulsory provision of ocular protective devices through policy initiatives must also be considered. The government of Ghana and all key stakeholders will need to work together to achieve these goals.

\section{Conflict of interest}

The authors declare no conflict of interest.

\section{References}

1. World Bank. Supply chain risk assessment: Cocoa in Ghana, Ghana Cocoa SCRA Report, 2011. [cited 2013 Jan 28]. Available from: https://www.agriskmanagementforum.org/sites/agriskmanagementforum.org/ files / Documents / Ghana $\% 20$ Cocoa $\% 20$ SCRA $\% 20$ Report $\% 202011 \% 20$ ARMT.pdf

2. Asuming-Brempong S, Sarpong DB, Asenso-Okyere $\mathrm{K}$, Amoo P. Labour practices in cocoa production in Ghana (pilot survey). 2006. [cited 2011 July 11]. Available from: http://www.aktiv-gegen-kinderarbeit.de.

3. Tutu K. Trade for Sustainable Development: The Story of Cocoa, Gold and Timber Exports in Ghana. Roundtable discussion organized by the Institute of Economic Affairs (IEA), Accra, 2011. Bus Fin Times. 2011; 12(9): $1-3$.

4. Dormon ENA, Van-Huis A, Leeuwis C, Obeng- Ofori D, Sakyi- Dawson O. Causes of low productivity of co- coa in Ghana: farmers' perspectives and insights from research and the socio- political establishment. NJAS Wageningen J. Life Sci. 2004; 11(3/4), 237- 259. doi: 10.1016/ S1573-5214(04)80016-2.

5. Amponsah-Tawiah K, Dartey-Baah K. Occupational Health and Safety: Key Issues and Concerns in Ghana. Int J Bus Soc Sci. 2011; 2(4):119-126.doi.org/10.5430/ijba. $\mathrm{v} 4 \mathrm{n} 2 \mathrm{p} 74$

6. Clarke E. Do occupational health services really exist in Ghana? In: S. Lehtinen, J. Rantanen, K. Elgstrand, J. Liesivuori, and Peurala, M. (eds,), Challenges of Occupational Health Services in the Regions. The National and International Responses, Proceedings of a WHO/ ICOH/ILO Workshop, 24 January, Finnish Institute of Occupational Health, Helsinki. 2005; 16-25.[accessed 2012 July 12]. Available from:http://www.rics.org/site/ download_feed.aspx?fileID $=8099 \&$ fileExtens

7. International Labour Organization [ILO]. List of Ratifications of International Labour Conventions, Ghana, 2013. [accessed 2013 May 4]. Available from: http:/ / webfusion.ilo.org/public/applis/applbyCtry. cfm?lang $=\mathrm{EN} \& \mathrm{CTYCHOICE}=1960$.

8. International Labour Organization. Convention 184. Convention concerning Safety and health in agriculture. 2001. [accessed 2012 Jan 22]. Available from:http:/ /www. ilo.org/public/english/standards/relm/ilc/ilc89/pdf/ c184.pdf.

9. Muilerman, S. Occupational Safety and Health on Ghanaian cocoa farms. Baseline report. Sustainable Tree Crops Program, International Institute of Tropical Agriculture (IITA), Accra, Ghana.2013. [accessed 2013 Oct 10]. Available from: http://www.iita.org/c/document_library $/$ get_file?uuid $=50 \mathrm{~b} 4 \mathrm{bf19}-\mathrm{b} 1 \mathrm{bd}-44 \mathrm{a} 2-9 \mathrm{ac} 0$ 56a590c7c36e\&groupId=25357.

10. Gyasi ME, Amoaku WMK, Adjuik MA. Epidemiology of hospitalized ocular injuries in the Upper East Region of Ghana. Gh Med J. 2007; 41( 4):171-175.PMCID: PMC2350113

11. Addisu Z. Pattern of ocular trauma seen in Grarbet Hospital, Butajira, Central Ethiopia. Ethiop J Health Dev. 2011; 25(2): 150-155. [accessed 2013 Sep 11].Available from: http://ejhd.uib.no/ejhd-v25 no2/150\%20 Pattern $\% 20$ of $\% 20$ ocular $\% 20$ trauma $\% 20$ seen $\% 20$ in $\% 20$ Grarbet $\% 20$ Hospital, \%20Butajira, $\% 20$ Central $\% 20$ Ethiopia.pdf.

12. Abraham D, Isseme I, Vitale S, West S. Epidemiology of eye injuries in rural Tanzania. Ophthalmic Epidemiol. 1999; 6 (2): 85-94. PMID:10420208. 
13. lsar M, Chirambo M, Belkin M. Ocular injuries in Malawi. Br JOphthalmol. 1982; 66: 145-148. PMID:7059557 14. Arcury TA, Vallejos QM, Schulz MR, Feldman SR, Fleischer AB, Verma A, Quandt SA. Green Tobacco Sickness and Skin Integrity among Migrant Latino Farmworkers. Am J Indus Med. 2008; 51:195-203. doi: 10.1002/ ajim.20553.

15. Magnani R, Sabin K, Saidel T, Heckathorn D. Review of sampling hard- to-reach and hidden populations for HIV surveillance. AIDS, 2005; 19 (suppl 2):S67-S72. PMID: 15930843

16. Aneani F, Anchirinah, VM, Owusu-Ansah F, Asamoah M. An analysis of the extent and determinants of crop diversification by cocoa (Theobroma cacao) farmers in Ghana. Afri J Agric Res. 2011; 6 (18): 4277-4287. doi: 10.5897/AJAR10.1083.

17. Larson B, Asuming-Brempong S, Sarpong D, Anim-Somuah H, Rosen S.Household Health and Cocoa Production: A Baseline Survey of Smallholder Farming Households in Western Region, Ghana. Health and Development Discussion Paper No. 6. Boston: Center for International Health and Development. 2005. [accessed 2013 June 19]. Available from:http://www.bu.edu/cghd/ files/2011/11/HDDP-No-6.-Nov-2005.-Larson-et-al. pdf.

18. Verma A, Schulz RM, Quandt SA, Robinson N E, Grzywacz GJ, Chen H Arcury TA. Eye Health and Safety among Latino Farmworkers. J Agromed. 2011; 16 (2): 143 152. doi: 10.1080/1059924X.2011.554772.

19. Quandt SA, Feldman RS, Vallejos MQ, Schulz RM, Verma A, Fleischer BA, Arcury AT. Vision Problems, Eye Care History, and Ocular Protection among Migrant Farmworkers. Arch Environ Occup Health. 2008; 63 (1), 136. doi: 10.3200/AEOH.63.1.13-16.

20. Quandt SA, Schulz RM, Talton WJ, Verma A, Arcury AT. Occupational Eye Injuries Experienced by Migrant Farmworkers. J Agromed, 2012; 17(1), 63-69.doi: 10.1080/1059924X.2012.629918.

21. Forst L, Noth IM, Lacey S, Bauer S, Skinner S, Petrea

$\mathrm{R}$, Zanoni J. Barriers and benefits of protective eyewear use by Latino farm workers. J Agromed, 2006; 11(2): 11-7. PMID:17135138

22. Minassian DC. Sample size calculation for eye surveys: a simple method.Comm Eye Health 1997; 10(23): 42-44. [accessed 2014 June 12]. Available from: http:// www.cehjournal.org/article/sample-size-calculation-foreye-surveys-a-simple-method.

23. Thompson GJ, Mollan SP. Occupational eye injuries: a continuing problem. Ocсир Med. 2009; 59:123-125. doi: 10.1093/occmed/kqn168

24. Chen S, Bartolucci AA, Bae S, Singh PK. Associating Risk Factors with Farm Injuries Using Classification Tree University of North Texas Health Science Center, 2007. [accessed 2013 May 21]. Available from: http:/ /www.stats. gov.cn/english/icas/papers/P020071114297552340662. pdf.

25. McGwin G Jr, Enochs R, Roseman JM. Increased risk of agricultural injury among African farm workers from Alabama and Mississippi. Am J Epidemiol. 2000; 152:640650. PMID:11032159.

26. Maltais V. Risk Factors Associated with Farm Injuries in Canada 1991-2001Statistics Canada - Agicultural Division- Catalogue no. 21-601-MIE. 2007.Available at http://publications.gc.ca/Collection/Statcan/21-601MIE/21-601-MIE2007084.pdf. (accessed June 12, 2014). 27. Woodward M. Epidemiology: Study Design and Data Analysis, 2nd ed. Boca Raton: Chapman \& Hall/CRC; 2005:152-153 , 250-251 PubMed.

28. Hill, P. The Migrant Cocoa Farmers of Southern Ghana. A Study in Rural Capitalism. Cambridge, UK:University Press.1963.

29. Teal F, Zeitlin A, Maamah H. Ghana Cocoa Farmers Survey 2004: Report to Ghana Cocoa Board." Centre for the Study of African Economics University of Oxford, Oxford, United Kingdom, 2006. [accessed 2013 April 22]. Available from: http://www.gprg.org/pubs/reports/pdfs/2006-04-teal-zeitlin-maamah.pdf

30. Anim-Kwapong GJ, Frimpong EB. Vulnerability of agriculture to climate change - impact of climate change on cocoa production: Cocoa Research Institute of Ghana, New-Tafo Akim, 2005. [accessed 2013 May 12]. Available from: http://www.nlcap.net/fileadmin/NCAP/Countries/Ghana/COCOA_DRAFT_FINAL_REPORT.pdf. 31. Van den Broucke S, Colémont A. Behavioral and Nonbehavioral Risk Factors for Occupational Injuries and Health Problems Among Belgian Farmers. J Agromed. 2011; 16(4): 299-310. doi: 10.1080/1059924X.2011.605709.

32. Khatry SK, Lewis AE, Schein OD, Thapa MD. The epidemiology of oculartrauma in rural Nepal. Br J OphthalmoI. 2004; 88: 456-460. doi: 10.1136/bjo.2003.030700 PubMed

33. McCurdy SA, Xiao H, Hennessy-Burt TE, StoecklinMarois MT, Tancredi DJ, Bennett DH, Marc B. Schenker MB. Agricultural Injury in California Hispanic Farm Workers: MICASA Follow-up Survey, J Agromed. 2013: 18(1): 39-49. doi: 10.1080/1059924X.2012.743380. 
34. McCall BP, Horwitz B, Taylor OA. Occupational eye injury and risk reduction: Kentucky workers' compensation claim analysis 1994-2003. Injury Prev. 2009;15:176182. doi:10.1136/ip.2008.020024.

35. Shashikala P, Sadiqulla M, Shivakumar D, Prakash $\mathrm{KH}$. Profile of ocular trauma in industries-related hospital. Indian J Occup Environ Med. 2013; 17(2): 66-70. doi: 10.4103/0019-5278.123168.

36. Tettey S, Ogoe M, Sonii D. Preventing and Reducing Injuries and Ill Health in Cocoa Production. Learning about Sustainable Cocoa Production: A Guide for Participatory FarmerTraining, manual no. 4, 2009. [accessed 2013 July 12]. Available from: http://www.iita.org/c/ document_library/get_file?p_1_id=98898\&folderId=33 9194\&name $=$ DLFE-1656.pdf

37. Ghana Statistical Service. Population and housing census, 2010. [accessed 2012 June 2]. Available from:http:// www.statsghana.gov.gh/docfiles/2010phc/Census2010_ Summary_report_of_final_results.pdf.

38. Ocansey S, Kyei S, Gyedu BN, Awuah A. Eye care seeking behaviour: a study of the people of Cape Coast
Metropolis of Ghana. J Behav Health. 2014; 3(2): 101-106. doi: 10.5455/jbh.20140219014308

39. Eze BI, Chuka-Okosa CM, Uche JN. Traditional eye medicine use by newly presenting ophthalmic patients to a teaching hospital in south-eastern Nigeria: socio-demographic and clinical correlates. BMC Comp Alt Med. 2009, 9:40doi:10.1186/1472-6882-9-40.

40. Chae H, Min K, Kanwoo Y, Park J, Kim K, Kim H, Lee K. Estimated rate of agricultural injury: the Korean Farmers' Occupational Disease and Injury Survey. Annls Occp Environ Med. 2014, 26 (8): 1-7. doi: 10.1186/20524374-26-8

41. Chatterjee S, Agrawal D, Sahu A, Dewangan D. Primary Prevention of Ocular Injury in Agricultural Workers with Safety Eye Wear. MGM Eye Institute, Raipur. 70th AIOC Proceedings, Cochin 2012. [accessed 2013 May 15]. Available from: http://www.aioseducation. org/2012/Free_Papers/OB3.pdf.

42. Ferguson C K, Gerberich SG, Church TR, Ryan AD, Alexander BH, Mongin SJ, Renier CM, Zhang X, French LR, Masten A. Tractor-Related Injuries: A PopulationBased Study of a Five-State Region in the Midwest. Am J Indus Med. 2005; 47: 254-264. doi: 10.1002/ajim.20135 